\title{
Extensive prekimberlitic lithosphere modification recorded in Jericho mantle xenoliths in kimberlites, Slave craton
}

\author{
STEPHANIE GREENE ${ }^{1}$, DORRIT E. JACOB ${ }^{1}$, SUZANNE Y. \\ O'REILLY ${ }^{1}$, HADRIEN HENRY ${ }^{1}$, ZSANETT PINTER ${ }^{2}$, \\ LARRY HEAMAN ${ }^{3}$
}

${ }^{1}$ CCFS, Dept. Earth and Enviro. Sciences, Macquarie Univ. *stephanie.greene@hdr.mq.edu.au

${ }^{2}$ Dept. Earth, Atmosphere and Enviro., Monash University

${ }^{3}$ Dept. Earth and Atmospheric Sciences, U. of Alberta.

Wehrlite and pyroxenite xenoliths and megacrysts from the Jericho kimberlite were analyzed by $\mu \mathrm{XRF}$ and EBSD, and for major elements, trace elements, and isotopes $(\mathrm{Pb}-\mathrm{Sr}-$ $\mathrm{O})$ in major phases. Thermobarometry places these samples at $60-180 \mathrm{~km}$ and $600-1200{ }^{\circ} \mathrm{C}$. While modes and textures vary, many samples have olivine-olivine grain boundaries with straight edges and $120^{\circ}$ angle junctions, indicating granoblastic recrystallisation, while clinopyroxene and orthopyroxene are complexly intergrown. Clinopyroxene twins and subgrains recording orientations distinct from the encapsulating grain were detected using EBSD and are inferred to represent recent modification processes. Several distinct garnet compositions were measured, with multiple thin garnet rims in some samples suggesting possible successive stages of garnet crystallisation. Complex chromium zoning in garnet is detected by $\mu \mathrm{XRF}$ in several samples (fig.1). $\mathrm{Pb}-\mathrm{Pb}$ ages for most samples are similar to the age of kimberlite entrainment $(173 \mathrm{Ma})$, but the shallowest pyroxenite sample preserves the most radiogenic $\mathrm{Pb}$ composition, intercecting concordia at $0.7-1.1 \mathrm{Ga}$, and is the only sample with $\delta^{18} \mathrm{O}$ above the mantle range $(6.2 \pm 0.1$ $\%$ ). The deepest sample has the lowest $\delta^{18} \mathrm{O}(5.5 \pm 0.1 \%)$ and radiogenic ${ }^{87} \mathrm{Sr} /{ }^{86} \mathrm{Sr}$ similar to MARID rocks $(0.709 \pm 1 \%)$. These results suggest the Jericho lithosphere experienced several melt/fluid injection events that modified substantial portions of the sampled section soon before kimberlite entrainment.

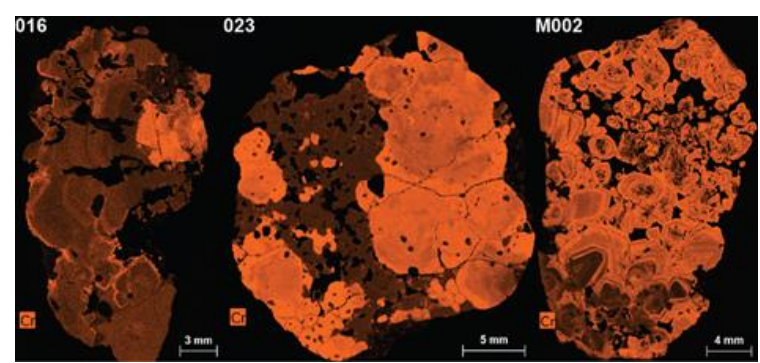

